\title{
Evaluation of the Financial Performance of Tourism Companies Traded in BIST via a Hybrid MCDM Model
}

\author{
Ahmet Aytekin
}

Faculty of Business Administration, Anadolu University

\begin{tabular}{l} 
ARTICLE INFO \\
\hline Keywords: \\
Tourism \\
Financial Performance \\
CRITIC \\
MAUT \\
PROMETHEE \\
TOPSIS \\
Borda
\end{tabular}

\section{Introduction}

Tourism, as a dictionary means, is a trip, tour or travel for resting, entertainment, sightseeing, and familiarization (TDK, 2019). Leiper (1979) defined tourism as an open system that provides individuals leaving their familiar place in voluntarily to spend time in a temporary place. The components of this system are tourists, generating tour regions, transit routes, arrival regions, and the tourism industry. On the other hand, tourism enterprises are economic organizations that aim to make a profit by meeting the tourist needs formed by these components. And, they produce touristic goods and services in this context. In the literature, it is stated that the tourism industry, which is formed by tourism enterprises, was born in 1950 and has an active, unusual and dynamic structure, patterned with tourism activities (Leiper, 1979; Özçelik \& Kandemir, 2015).

The tourism industry has made progress since its inception. Nowadays, it is seen that the tourism industry not only contributes to international peace and understanding but also positively affects countries' economies. Especially in developing and underdeveloped countries that do not have sufficient capital, tourism can provide foreign exchange with fewer resources in a short time and enable them to improve their balance of payments. Besides, the tourism sector continues its growth trend worldwide. This trend can be seen in tourism statistics. In

* Corresponding Author E-Mail Address: ahmetaytekin@anadolu.edu.tr 
2018, the number of tourists entering countries reached 1,4 billion. Also, the sector provided $10,4 \%$ of GDP and one-fifth of the jobs created in the last five years. The number of employments created by the tourism sector has increased to 319 million. Also, the economic size of the sector increased to $\$ 8,811$ billion in 2018 , while this figure is expected to be $\$ 9,126$ billion in 2019 (Travel \& Tourism Economic Impact 2019).

Similar to the world, tourism has an important place in Turkey. Tourism is a sector that stands out with its features narrowing the foreign trade deficit and providing employment in Turkey. The data in Table 1 shows the impact of developments in the last 5 years for tourism in Turkey.

Table 1.

Macro Tourism Data for Turkey in the Period of 2014-2018

\begin{tabular}{lccccc}
\hline Indicator & $\mathbf{2 0 1 4}$ & $\mathbf{2 0 1 5}$ & $\mathbf{2 0 1 6}$ & $\mathbf{2 0 1 7}$ & $\mathbf{2 0 1 8}$ \\
\hline Tourism revenue $(\$ 1,000)$ & 34.305 .904 & 31.464 .777 & 22.107 .440 & 26.283 .656 & 29.512 .926 \\
Tourism expenditure $(\$ 1,000)$ & 5.470 .481 & 5.698 .423 & 5.049 .793 & 5.137 .243 & 4.896 .310 \\
Number of citizens visiting abroad & 7.982 .264 & 8.750 .851 & 7.891 .909 & 8.886 .917 & 8.383 .432 \\
Personal expenditure of citizens visiting abroad $(\$ 1,000)$ & 4.432 .386 & 4.768 .443 & 4.031 .516 & 4.095 .120 & 3.936 .986 \\
Number of departing visitors & 41.415 .070 & 41.617 .531 & 31.365 .330 & 38.620 .346 & 45.628 .673 \\
Personal expenditure of departing visitors $(\$ 1,000)$ & 26.002 .950 & 24.788 .321 & 18.495 .978 & 21.461 .603 & 22.546 .616 \\
The ratio of tourism revenues to export revenues & 21,8 & 21,9 & 15,5 & 16,7 & 17,5 \\
The ratio of tourism revenues to import expenditures & 2,2 & 2,8 & 2,5 & 2,2 & 2,2 \\
\hline
\end{tabular}

Source: https://biruni.tuik.gov.tr/medas/?kn=74\&locale=tr \& https://www.tursab.org.tr/istatistikler (Access date: 10.07.2019)

Table 1 shows that Turkey's tourism revenues and expenses declined after 2014, and its share in GDP declined to $3.8 \%$ in 2018. The most important reasons for this are the growth of terrorism effect domain globally, economic crises and regional crises such as the civil war in Syria. However, the recoveries experienced since 2017 have continued increasing, and thus the sector has started to recover its lost ground. When the position of tourism in Turkey is considered, this development looks promising for the future. Because the tourism industry has a positive impact on the economy, provides employment, and gives vitality to sectors such as transportation, trade, construction, health and sociological and cultural effects (Bozgeyik \& Yoloğlu, 2015; Topalli, 2015).

On the other hand, tourism is a sector that requires large investments and the return on this investment takes a long time. Besides, the importance of tourism in terms of investors, connected sectors and national economy makes necessary to evaluate the financial performance of the tourism companies. Therefore, evaluating the financial performance of tourism companies will provide some information to these stakeholders, and reveal the rationality of the existing and future investments.

The investigation made in the context of tourism facilities and operations in Turkey shows that there are 3934 tourism operation certificated, 984 tourism investment licensed and 7685 municipal tourist certified facilities (TURSAB, 2019). However, the numbers of tourism companies are just six in Tourism Index (XTURIZM) in BIST (Istanbul Stock Exchange). BIST is only one exchange market where companies are publicly traded in Turkey. On the other hand, some companies are traded in different indices but whose main activity is tourism. In this context, the study aimed to evaluate the financial performance of publicly-traded tourism companies in Turkey.

As a result of queries made in Thomson Reuters, the data are obtained for tourism companies such as Altın Yunus Çeşme Touristic Facilities Inc. (AYCES), Marmaris Altınyunus Touristic Facilities Inc. (MAALT), Martı Hotel Management Inc. (MARTI), Metemtur Hospitality and Tourism Enterprises Inc. (METUR), Net Holding Inc. (NTHOL), Petrokent Tourism Inc. 
(PKENT), Tek-Art Construction, Trade, Tourism Industry and Investments Inc. (TEKTU), Utopya Tourism, Construction, Management Trade Inc. (UTYPA) and Ulaşlar Tourism Investments and Durable Consumer Goods Trade Marketing Inc. (ULAS).

The following section includes the literature on the financial performances of Turkish publiclytraded tourism companies and the financial ratios used in the study. Then, the methods section gives explanations of the techniques used in the study. Finally, the results and conclusions obtained in this study are presented.

\section{Literature}

BIST provides opportunities for investors to invest in companies of their choice. Although companies from different sectors are included in the BIST, the subject of the study is to evaluate the financial performance of Turkish publicly-traded tourism companies.

Financial performance shows whether companies use their resources effectively and efficiently in line with their targets. Financial performance analysis gives information about the financial position of the companies. The companies evaluate this information and give decisions related to their future. Financial ratios are frequently used in financial performance analysis. Financial ratios are obtained by proportioning the information in the financial statements of the companies. It is possible to sum these ratios under the indicators of liquidity, financial structure, activity, and profitability. The most commonly used financial ratios in the literature are current ratio, quick ratio, cash ratio, debt ratio, total debt/common equity ratio, net margin, return on equity, interest coverage ratio, total asset turnover rate, inventory turnover rate, receivables turnover rate (Karadeniz et al., 2016).

In literature, these ratios and multiple criteria decision making (MCDM) techniques were mainly used together for financial performance analyses of tourism companies. In the following paragraphs, these studies will be briefly discussed.

Ergül (2014) evaluated the financial performance of seven companies listed in the BISTTourism sector between 2005-2012. For this purpose, MCDM techniques ELECTRE-III (ELimination ET Choix Traduisant la REalite-III) and TOPSIS (Technique for Order Preference by Similarity to Ideal Solution) were used. It was stated that the order of TOPSIS and ELECTRE are close to each other. During the evaluation period, it was found that MAALT, NETTUR and PKENT companies performed better than other companies.

Ecer and Günay (2014) analyzed the financial performance of nine tourism companies listed in BIST via GRA (Grey Relation Analysis) from 2008 to 2012. In the study, seventeen financial ratios within the scope of liquidity, leverage, profitability, and activity indicators are used, and the most important of these is reported as the leverage indicator.

Özçelik and Kandemir (2015) evaluated the financial performance of tourism companies traded in BIST between 2010 and 2014 using TOPSIS. The authors used liquidity, leverage, profitability and operating rates as criteria.

Yakut et al. (2015) analyzed the efficiency of nine companies listed in BIST between 2009 and 2013 via DEA (Data Envelopment Analysis). It was concluded that only three of these companies had fully effective performance in all years.

Karadeniz et al. (2016) examined the financial performances of the BIST tourism sub-sectors using GRA. Liquidity, financial structure, asset utilization, and profitability ratios were used in the study. Among these, the most important one is the financial structure. Besides, travel agencies were stated as the most successful financial sector of sub-sectors.

Kendirli and Çankaya (2016) evaluated tourism companies traded in 2010-2014 in terms of operating capital management and profitability. The results exhibited a positive and significant relationship between working capital management and asset profitability.

Karaca and Ören (2017) investigated the tourism companies' bankruptcy risk. For this purpose, the authors evaluated the tourism companies traded in BIST between 2009 and 2016 via the 
Altman Z Model using the financial statement data. They stated that the bankruptcy risk of tourism companies increased especially after the plane crisis with Russia, but there was no significant decrease in stock market values.

Karkacier and Yazgan (2017) evaluated the financial performances of ten tourism companies listed in BIST in 2015 using GRA. In the study, it is stated that leverage ratios are more important than other ratios.

Erdoğan and Yamaltdinova (2018) evaluated the financial performance of thirteen tourism companies listed in BIST in 2011-2015 via TOPSIS. The authors stated that the financial performance of the companies was unstable for this period.

Considering the similarity of these studies and the indicators, eleven ratios consisting of these indicators were used in this study. For this purpose, current ratio, quick ratio, and cash ratio were determined as liquidity indicators. Debt ratio, total debt/common equity ratio were used as financial structure indicators. Net margin, return on equity, and interest coverage ratios were assessed as profitability indicators. Finally, total asset turnover rate, inventory turnover rate, and receivables turnover rate were designated as activity/asset utilization indicators. The calculation of the related ratios is given in Table 2 .

Table 2.

Calculation of financial ratios

\begin{tabular}{|c|c|c|c|}
\hline Ratio & Notation & Computation & Optimization \\
\hline Current ratio & $\mathrm{K}_{1}$ & $\mathrm{~K}_{1}=\frac{\text { Current Assets-Total }}{\text { Current Liabilities-Total }}$ & $\max$ \\
\hline Quick ratio & $\mathrm{K}_{2}$ & $\mathrm{~K}_{2}=\frac{\text { Net Income }- \text { Bottom Line }}{\text { Net Sales or Revenues }} * 100$ & $\max$ \\
\hline Cash ratio & $\mathrm{K}_{3}$ & $\mathrm{~K}_{3}=\frac{\text { Cash\&Equivalents }+ \text { Receiavables }(\mathrm{Net})}{\text { Current Liabilities-Total }}$ & $\max$ \\
\hline $\begin{array}{l}\text { Debt } \\
\text { (leverage) } \\
\text { ratio }\end{array}$ & $\mathrm{K}_{4}$ & $\mathrm{~K}_{4}=\frac{\text { Cash\&Equivalents }}{\text { Current Assets-Total }} * 100$ & $\min$ \\
\hline $\begin{array}{l}\text { Total debt / } \\
\text { common } \\
\text { equity }\end{array}$ & $\mathrm{K}_{5}$ & $\mathrm{~K}_{5}=\frac{\text { Long Term Debt }+ \text { Short Term Debt\&Current Portion of Long Term Debt }}{\text { Total Capital+Short Term Debt\&Current Portion of Long Term Debt }} * 100$ & $\min$ \\
\hline Ratio & Notation & Computation & Optimization \\
\hline Net margin & $\mathrm{K}_{6}$ & $\mathrm{~K}_{6}=\frac{\text { Long Term Debt }+ \text { Short Term Debt\&Current Portion of Long Term Debt }}{\text { Common Equity }} * 100$ & $\max$ \\
\hline $\begin{array}{l}\text { Return on } \\
\text { equity }\end{array}$ & $\mathrm{K}_{7}$ & $\mathrm{~K}_{7}=\frac{\text { Net Income-Bottom Line-Preferred Dividend Requirement }}{\text { Avg. of Last Year'sand Current Year's Common Equity }} * 100$ & $\max$ \\
\hline $\begin{array}{l}\text { Interest } \\
\text { coverage } \\
\text { ratio }\end{array}$ & $\mathrm{K}_{8}$ & $\mathrm{~K}_{8}=\frac{\text { Earnings Before Interest and Taxes }}{\text { Interest Expense on Debt }}$ & $\max$ \\
\hline $\begin{array}{l}\text { Asset } \\
\text { turnover rate }\end{array}$ & $\mathrm{K}_{9}$ & $\mathrm{~K}_{9}=\frac{\text { Net Sales or Revenues }}{\text { Total Assets }}$ & $\max$ \\
\hline $\begin{array}{l}\text { Inventory } \\
\text { turnover rate }\end{array}$ & $\mathrm{K}_{10}$ & $\mathrm{~K}_{10}=\frac{\text { Costs of Goods Sold (Excl Depreciation) }}{\text { Avg. of Last Year'sand Current Year's Inventors }}$ & $\max$ \\
\hline $\begin{array}{l}\text { Receivables } \\
\text { turnover rate }\end{array}$ & $\mathrm{K}_{11}$ & $\mathrm{~K}_{11}=\frac{\text { Cost of Goods Sold (Excl Depreciation) }}{\text { Receivables (Net) }}$ & $\max$ \\
\hline
\end{tabular}

Source:https://blogs.cul.columbia.edu/business/files/2014/02/Worldscope-Data-Definition-GuideIssue-14.2.pdf (Access date: 11.07.2019)

Liquidity ratios, one of the four main indicator groups, indicate the ability of the enterprise to pay short-term debts and whether the working capital is sufficient. For tourism companies, the 
ratios' aspiration values from this group are 2 for cash ratio, 1 for quick ratio, and 0.20 for cash ratio. Financial structure ratios are used to determine the relationship between equity and liabilities. The financial structure ratios' expected values are 0.5 for debt (leverage) ratio, and to be less than 1 for total debt / common equity ratio. Activity indicators reveal the relationship between the sales and assets of the enterprise. In other words, turnover rates indicate the effectiveness of the usage of the entity's assets. In general, the high rate of these assets indicates the effectiveness of the usage of assets and the rapidity of conversion to money. Lastly, profitability ratios show whether the profitability of the company is sufficient. These ratios are also required to be high (Karadeniz et al., 2016).

\section{Method}

In order to evaluate the financial performance of tourism companies traded in BIST in 20142018, MCDM techniques MAUT, TOPSIS, and PROMETHEE were used. Among these techniques, MAUT is based on utility theory while PROMETHEE is an outranking-based technique. On the other hand, TOPSIS is one of the distances (compromise solution) based techniques. Thus, it is aimed to obtain the most effective result by approaching the decision problem via a hybrid model considering different three approaches of MCDM. Besides, the CRITIC technique was applied for weighting the criteria and the Borda technique was used for aggregating the results. The hybrid model is outlined below.

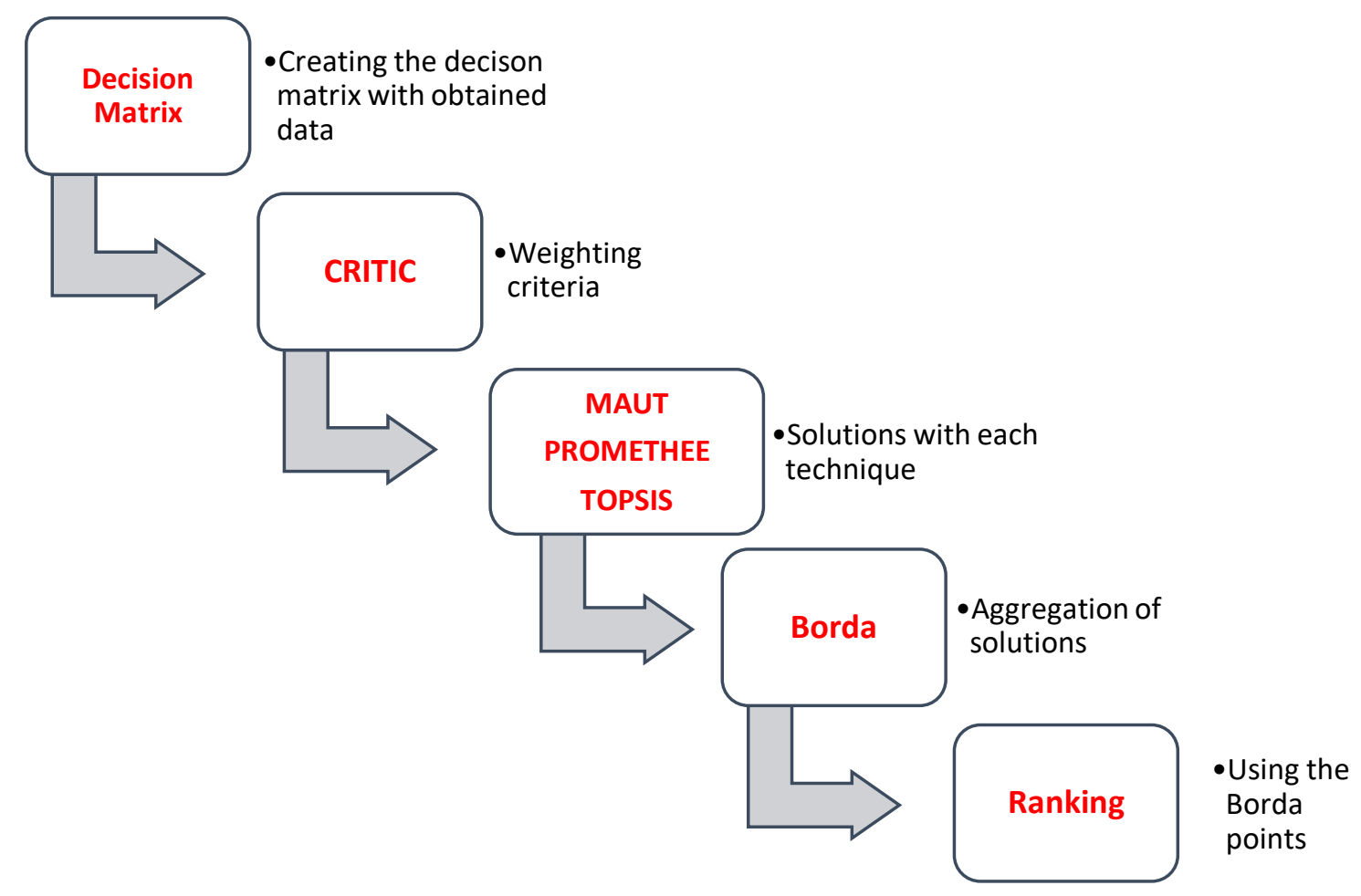

Figure 1. The Hybrid Model

To analyze with MCDM techniques, a decision matrix should be generated. The decision matrix includes each alternative's performance value according to evaluation criteria. For this purpose, the decision matrix was formed by using the financial ratios of the tourism companies. The decision matrix $X$ is an $(m x n)$ matrix, and whose elements are shown as $x_{i j}$ where $j=1 \ldots$ $\mathrm{n}$ as criteria and $\mathrm{i}=1, \ldots, \mathrm{m}$ as alternatives. It is denoted below: 


$$
\mathrm{X}=\left[\begin{array}{cccc}
\mathrm{X}_{11} & \mathrm{x}_{12} & \ldots & \mathrm{x}_{1 \mathrm{n}} \\
\cdot & \ldots & \cdots & \cdot \\
\cdot & \ldots & \ldots & \cdot \\
\mathrm{x}_{\mathrm{m} 1} & \mathrm{x}_{\mathrm{m} 2} & \ldots & \mathrm{x}_{\mathrm{mn}}
\end{array}\right]
$$

The following sections include the application steps of MCDM techniques used in this study.

\subsection{CRITIC}

CRITIC (Criteria Importance through Inter-Criteria Correlation) was developed by Diakoulaki et al. (1995). CRITIC is a technique aimed at objective weighting by taking into account the correlation of criteria each other. The application steps of the CRITIC technique are presented below:

Step 1 Normalization of the decision matrix: To normalize the decision matrix, the equation (2) is used:

$$
N_{i j}= \begin{cases}\frac{x_{i j}-\min \left(x_{i j}\right)}{\max \left(x_{i j}\right)-\min \left(x_{i j}\right)} & \text { if optimization aspect is max } \\ \frac{\max \left(x_{i j}\right)-x_{i j}}{\max \left(x_{i j}\right)-\min \left(x_{i j}\right)} & \text { if optimization aspect is min }\end{cases}
$$

Step 2 Calculation of information values of criteria: Linear correlations $\left(\mathrm{r}_{\mathrm{jk}}\right)$ of each $\mathrm{j}$ criterion to the other k criteria are calculated. At this point, the Spearman rank correlation coefficient can also be used for criteria having ordinal measurement. Then, conflict values $\left(1-\mathrm{r}_{\mathrm{jk}}\right)$ are obtained over the correlation values. After this, using the standard deviation $\left(\sigma_{j}\right)$ as a measure of the contrast of each criterion, the amount of information $\left(C_{j}\right)$ of each $j$ criterion is calculated as follows:

$$
\mathrm{C}_{\mathrm{j}}=\sigma_{\mathrm{j}} \sum_{\mathrm{k}=1}^{\mathrm{m}}\left(1-\mathrm{r}_{\mathrm{jk}}\right)
$$

Step 3 Obtaining the criteria weight: As the $\mathrm{C}_{\mathrm{j}}$ value increases, the amount of information transmitted by the criterion will be more. In the last step, the weight value of each criterion is obtained using normalized $\mathrm{C}_{\mathrm{j}}$ values (Diakoulaki et al. 1995):

$$
\mathrm{W}_{\mathrm{j}}=\frac{\mathrm{C}_{\mathrm{j}}}{\sum_{\mathrm{k}=1}^{\mathrm{m}} \mathrm{C}_{\mathrm{j}}}
$$

The CRITIC technique was used in this study since it takes into account the correlations between the criteria. Thus, it was aimed to reflect effect levels of interrelated or conflicting criteria as objectively as possible on the solution of the problem.

\subsection{MAUT}

The Multi-Attribute Utility Theory (MAUT) technique is based on the Anglo-Saxon or American School tradition. American School Tradition puts forwards the idea that each decision-maker (DM) has a function to optimize his/her utility in a decision problem. According to this idea, the preferences of each DM can be characterized by a utility function (U). The MAUT technique is the embodiment of this thought in its most fundamental form. The utility function in MAUT can be linear, logarithmic, exponential, quadratic or other forms. Also, additive or multiplicative models are used to aggregate the performance values of the alternatives calculated within the criteria. However, the linear utility function and additive model are widely used in the literature (Ishizaka and Nemery, 2013). In this study, linear utility function and additive model were used. The application steps of the MAUT technique are as follows: 
Step 1 Normalization of the decision matrix: The equation (2) is used for normalizing the decision matrix. In this study, the normalized values $\left(\mathrm{N}_{\mathrm{ij}}\right)$ are used as utility values for the alternative of $\mathrm{i}$ for criterion $\mathrm{j}$.

Step 2 Weighting the normalized decision matrix: The criteria weights obtained in CRITIC can be used in MAUT. In this context, the following equation can be written:

$$
\mathrm{f}_{\mathrm{ij}}=\mathrm{N}_{\mathrm{ij}} \mathrm{w}_{\mathrm{j}}
$$

Step 3 Ranking alternatives: $\mathrm{U}_{\mathrm{i}}$ values are calculated for each alternative.

$$
\mathrm{U}_{\mathrm{i}}=\sum_{\mathrm{j}=1}^{\mathrm{n}} \mathrm{f}_{\mathrm{ij}}
$$

Alternatives are ranked in descending order of the $U_{i}$ values. And thus, the solution of the decision problem is completed.

\subsection{PROMETHEE}

PROMETHEE (Preference Ranking Organization Method for Enrichment Evaluation) is an outranking-based MCDM technique that allows DM to choose, rank or sort among alternatives over her/his preferences. Outranking-based techniques are derived from the French School tradition. In general, this tradition is dominated by the opinion that the utility cannot be measured, but the outranking of alternatives to each other can be determined within each criterion. And thus, the general solution is sought over these relations.

In terms of pairwise comparison of two alternatives in a criterion, one of the alternatives can be absolutely superior to the other, or moderate superior. Also, the relation can be indifferent (equal) or incomparable for these alternatives. Outranking-based techniques are distinguished from utility-value theory (American School Tradition) techniques in these aspects.

PROMETHEE is one of the most widely used outranking-based MCDM techniques (Durucasu et al., 2017). This technique was first proposed by Jean-Pierre Brans for partial ranking of alternatives, and then the PROMETHEE II derivative was developed to provide a complete ranking of alternatives. Today, PROMETHEE-II is the most used derivate of PROMETHEE while it is also possible to see numerous modified examples of PROMETHEE such as III, IV, V, VI, Sort (Ishizaka and Nemery, 2013; Durucasu et al. 2017).

In this study, it is aimed to make a full ranking of alternatives. In this context, PROMETHEE II was used. The implementation steps of PROMETHEE II are as follows:

Step 1 Weighting criteria if necessary: DM can weigh the criteria subjectively or objectively. For this purpose, scientific tools or techniques can be used. CRITIC technique was used in this study.

Step 2 Determination of preference functions by creating preference structures for each criterion: For this purpose, alternative pairs in each criterion is evaluated according to one of the appropriate PROMETHEE preference functions. These function types are usual, U, V, level, linear and Gaussian form. These functions' parameters and calculations are given in the table below (Brans and Vincke, 1985; Durucasu et al., 2017). 
Table 3.

PROMETHEE Preference Functions

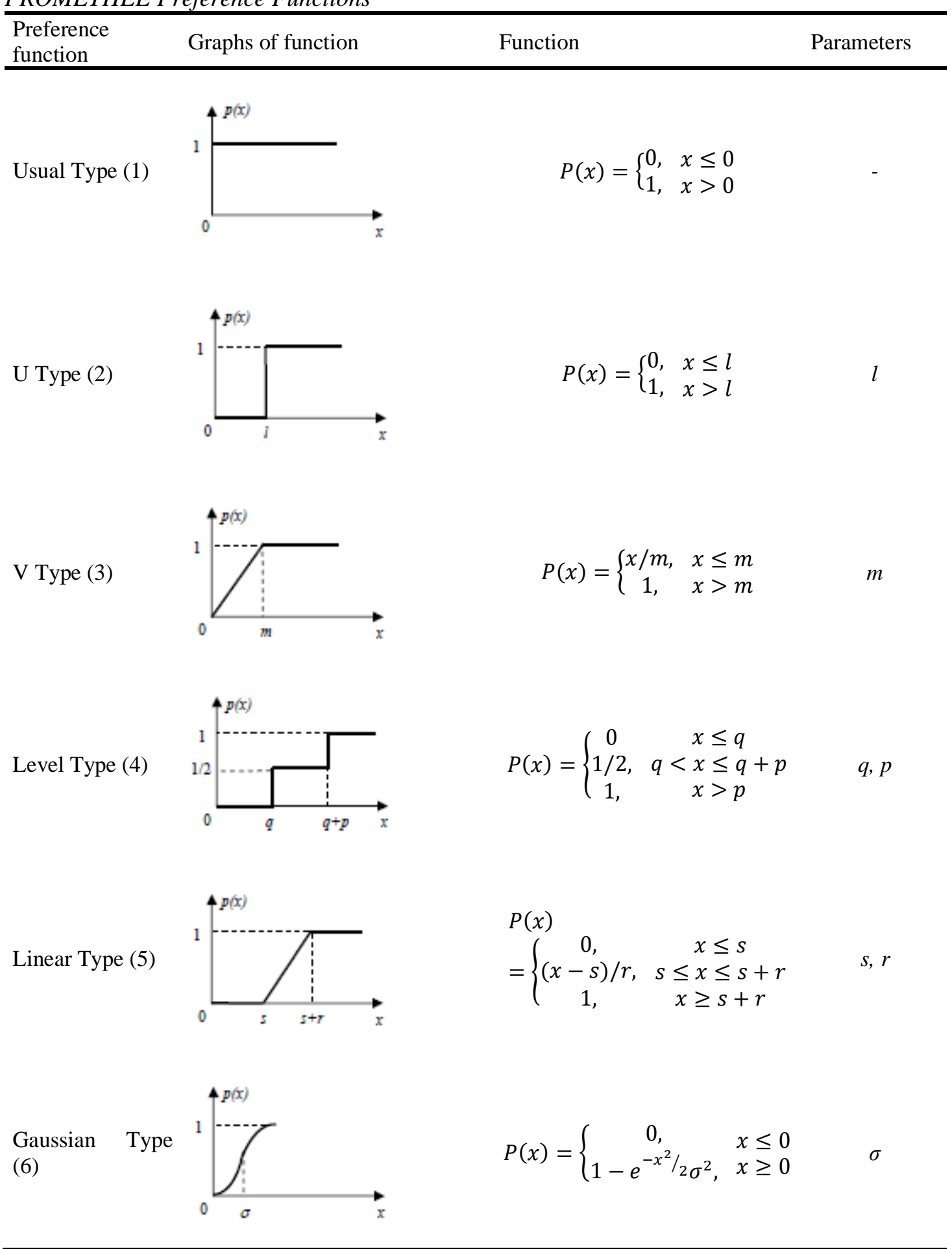

Source: Brans \& Vincke, 1985; Durucasu et al., 2017.

Step 3 Calculation of preference indices: Preference indices for alternative pairs are calculated using preference functions. For this purpose, the following equation is used for the alternative pair $\mathrm{Y}$ and $\mathrm{Z}$ in criterion $\mathrm{j}$ :

$$
\pi(Y, Z)=\sum_{j=1}^{n} w_{j} P_{j}(Y, Z) \quad j=1, \ldots, n
$$


Step 4 Calculation of positive (leaving) and negative (entering) flow values: In this step, positive $\left(\varphi^{+}\right)$and negative $\left(\varphi^{-}\right)$flow values for each alternative are calculated. For alternative $\mathrm{Z}$, where the number of alternatives is $\mathrm{m}$, the positive and negative flow are obtained from $\mathrm{d}$ alternatives, except for itself, with the following equation:

$$
\begin{gathered}
\varphi^{+}=\frac{1}{\mathrm{~m}} \sum \pi(\mathrm{Z}, \mathrm{d}) \\
\varphi^{-}=\frac{1}{\mathrm{~m}} \sum \pi(\mathrm{d}, \mathrm{Z})
\end{gathered}
$$

Step 5 Ranking alternatives by calculating net (full priority) flow values: The positive and negative flows are not sufficient for complete ranking. For this reason, the net flow values are calculated in PROMETHEE II. The following equation is used for this:

$$
\varphi(Z)=\varphi^{+}(Z)-\varphi^{-}(Z)
$$

Alternatives are ranked in descending order of net flow values, and the solution of the decision problem is completed.

\subsection{TOPSIS}

The TOPSIS technique was proposed by Yoon and Hwang in 1980 as a distance and compromise solution-based technique (Hwang and Yoon, 1981). The application steps of the technique are as follows:

Step 1 Normalization of the decision matrix with vector normalization: To normalize the decision matrix, the equation (12) is used:

$$
\mathrm{N}_{\mathrm{ij}}=\frac{\mathrm{x}_{\mathrm{ij}}}{\sqrt{\sum_{\mathrm{i}=1}^{\mathrm{m}} \mathrm{x}_{\mathrm{ij}}^{2}}}
$$

Step 2 Weighting the normalized matrix: Criteria weights are multiplied by normalized values to obtain a normalized weighted decision matrix. For this purpose, equation (5) is used.

Step 3 Generating ideal $\left(\varphi^{+}\right)$and negative ideal $\left(\varphi^{-}\right)$solution: In each criterion, ideal $\left(\varphi^{+}\right)$ indicates aspired value while negative ideal $\left(\varphi^{-}\right)$is undesirable value. In this context, the ideal and negative ideal values are determined according to the optimization aspect of the criterion as follows:

$$
\begin{aligned}
\varphi_{j}^{+} & =\left\{\begin{array}{l}
\max \left(f_{i j}\right) \text { if the optimization aspect of } j \text { is max } \\
\min \left(f_{i j}\right) \text { if the optimization aspect of } j \text { is min }
\end{array}\right. \\
\varphi_{j}^{-} & =\left\{\begin{array}{l}
\min \left(f_{i j}\right) \text { if the optimization aspect of } j \text { is max } \\
\max \left(f_{i j}\right) \text { if the optimization aspect of } j \text { is min }
\end{array}\right.
\end{aligned}
$$

Step 4 Obtaining distances from ideal $\left(\varphi^{+}\right)$and negative ideal $\left(\varphi^{-}\right)$: In TOPSIS, the distances from the ideal and negative ideal points are calculated with the Euclidean distance measure. The distance from the ideal point is indicated as $\mathrm{d}^{+}$while the distance from the negative ideal point is indicated by $\mathrm{d}^{-}$. And, the following equations are used for them:

$$
\begin{aligned}
& \mathrm{d}_{\mathrm{i}}^{+}=\sqrt{\sum_{\mathrm{j}=1}^{\mathrm{n}}\left(\mathrm{f}_{\mathrm{ij}}-\varphi_{\mathrm{j}}^{+}\right)^{2}} \\
& \mathrm{~d}_{\mathrm{i}}^{-}=\sqrt{\sum_{\mathrm{j}=1}^{\mathrm{n}}\left(\mathrm{f}_{\mathrm{ij}}-\varphi_{\mathrm{j}}^{-}\right)^{2}}
\end{aligned}
$$

Step 5 Calculating the relative proximity to the ideal solution and ranking the alternatives: The relative proximity $\left(\mathrm{C}_{\mathrm{i}}\right)$ of each alternative to the ideal solution is calculated as below:

$$
\mathrm{C}_{\mathrm{i}}=\mathrm{d}_{\mathrm{i}}^{-} /\left(\mathrm{d}_{\mathrm{i}}^{+}+\mathrm{d}_{\mathrm{i}}^{-}\right)
$$


The relative proximity values $(\mathrm{Ci})$ take values in the range of $0-1$. Alternatives are ranked in descending order according to $\mathrm{C}_{\mathrm{i}}$ values.

MAUT, PROMETHEE, and TOPSIS are widely used in MCDM techniques. On the other hand, the basic idea behind each is different from the others. For this reason, it is aimed to effectively reflect these three fundamental MCDM views to the solution of the problem. In this context, Borda, one of the aggregation techniques, was used to integrate the results obtained by three techniques.

\subsection{Borda}

The Borda technique is named after Jean-Charles de Borda (1770), who developed the Borda system. This technique, which is frequently used in social choice or voting problems, is used for aggregation in MCDM problems. For this purpose, from the ranking of $\mathrm{m}$ alternatives, $\mathrm{m}$ 1 points are given to the first place, $\mathrm{m}-2$ points to the second place, while the similar process is being made for other alternatives whereas 0 points fall to the last ranked alternative (Lansdowne \& Woodward, 1996; Lippman, 2017). In other words, while i.th alternative's rank position is indicated as $S_{i}$, Borda point for alternative $\mathrm{i}$ is obtained as below:

$$
\mathrm{B}_{\mathrm{i}}=\mathrm{m}-\mathrm{S}_{\mathrm{i}}
$$

After the Borda points are calculated, the alternatives are ranked according to these points in descending orders, and the solution of the decision problem is completed.

\section{Results}

The data for the companies evaluated in the study were obtained from Thompson Reuters Datastream. These data were used to form the decision matrices for each year. Then the weight values for each year were determined by the CRITIC technique. In this context, the weights are presented in Table 4.

Table 4.

Weights of the Criteria

\begin{tabular}{cccccc}
\hline \multirow{2}{*}{ Criteria } & \multicolumn{5}{c}{ Years } \\
\cline { 2 - 6 } & 2014 & 2015 & 2016 & 2017 & 2018 \\
\hline $\mathrm{K}_{1}$ & 0,075 & 0,069 & 0,065 & 0,085 & 0,068 \\
$\mathrm{~K}_{2}$ & 0,074 & 0,090 & 0,095 & 0,077 & 0,067 \\
$\mathrm{~K}_{3}$ & 0,090 & 0,104 & 0,111 & 0,076 & 0,069 \\
$\mathrm{~K}_{4}$ & 0,131 & 0,064 & 0,065 & 0,069 & 0,085 \\
$\mathrm{~K}_{5}$ & 0,080 & 0,066 & 0,082 & 0,079 & 0,171 \\
$\mathrm{~K}_{6}$ & 0,062 & 0,092 & 0,122 & 0,076 & 0,063 \\
$\mathrm{~K}_{7}$ & 0,077 & 0,109 & 0,068 & 0,076 & 0,106 \\
$\mathrm{~K}_{8}$ & 0,112 & 0,061 & 0,087 & 0,110 & 0,090 \\
$\mathrm{~K}_{9}$ & 0,136 & 0,133 & 0,101 & 0,148 & 0,147 \\
$\mathrm{~K}_{10}$ & 0,073 & 0,108 & 0,121 & 0,089 & 0,067 \\
$\mathrm{~K}_{11}$ & 0,092 & 0,104 & 0,083 & 0,115 & 0,069 \\
\hline
\end{tabular}

CRITIC is a technique that provides objective weighting through correlations of data. When Table 4 is analyzed, it is seen that the asset turnover rate is relatively more important than the other criteria except for 2016. At this point, it is deduced that the capacity occupancy and sales in the tourism sector is more important in general. On the other hand, in 2016, which is one of the worst seasons for the Turkish tourism sector, the companies inclined to get more profitability because of the anticipation that capacity fullness could not be achieved. 
After the weighting of the criteria was completed, MAUT, PROMETHEE, and TOPSIS techniques were applied separately for each year's evaluation. MS Excel was used for the solutions made with MAUT and TOPSIS, and Visual PROMETHEE software was used for PROMETHEE. The results obtained with each technique were integrated with the Borda technique. Thus, each alternative has one Borda point for each year. In the last step, the rankings of the alternatives were obtained by using Borda points. The relevant results are given in Table 5.

Table 5.

Results

\begin{tabular}{|c|c|c|c|c|c|c|c|c|c|c|}
\hline \multirow{2}{*}{ Years } & \multirow{2}{*}{ Technique } & \multicolumn{9}{|c|}{ Ranking of companies and Borda points } \\
\hline & & AYCES & MAALT & MARTI & METUR & NTHOL & PKENT & TEKTU & UTPYA & ULAS \\
\hline \multirow{5}{*}{2014} & MAUT & 2 & 1 & 9 & 7 & 5 & 3 & 4 & 8 & 6 \\
\hline & PROMETHEE & 3 & 1 & 9 & 5 & 4 & 6 & 2 & 7 & 8 \\
\hline & TOPSIS & 3 & 1 & 9 & 2 & 6 & 5 & 4 & 8 & 7 \\
\hline & Borda points & 19 & 24 & 0 & 13 & 12 & 13 & 17 & 4 & 6 \\
\hline & $\begin{array}{l}\text { Aggregated } \\
\text { Rank }\end{array}$ & 2 & 1 & 9 & 4 & 6 & 4 & 3 & 8 & 7 \\
\hline \multirow{5}{*}{2015} & MAUT & 4 & 1 & 8 & 2 & 5 & 6 & 3 & 7 & 9 \\
\hline & PROMETHEE & 5 & 1 & 9 & 2 & 4 & 6 & 3 & 7 & 8 \\
\hline & TOPSIS & 6 & 1 & 9 & 2 & 4 & 5 & 3 & 8 & 7 \\
\hline & Borda points & 12 & 24 & 1 & 21 & 14 & 10 & 18 & 5 & 3 \\
\hline & $\begin{array}{l}\text { Aggregated } \\
\text { Rank }\end{array}$ & 5 & 1 & 9 & 2 & 4 & 6 & 3 & 7 & 8 \\
\hline \multirow{5}{*}{2016} & MAUT & 4 & 2 & 9 & 1 & 3 & 6 & 5 & 7 & 8 \\
\hline & PROMETHEE & 4 & 1 & 9 & 2 & 3 & 7 & 5 & 8 & 6 \\
\hline & TOPSIS & 5 & 2 & 7 & 1 & 3 & 6 & 4 & 9 & 8 \\
\hline & Borda points & 14 & 22 & 2 & 23 & 18 & 8 & 13 & 3 & 5 \\
\hline & $\begin{array}{l}\text { Aggregated } \\
\text { Rank }\end{array}$ & 4 & 2 & 9 & 1 & 3 & 6 & 5 & 8 & 7 \\
\hline \multirow{5}{*}{2017} & MAUT & 4 & 1 & 9 & 7 & 3 & 5 & 6 & 8 & 2 \\
\hline & PROMETHEE & 4 & 1 & 9 & 7 & 2 & 6 & 5 & 8 & 3 \\
\hline & TOPSIS & 5 & 1 & 9 & 7 & 4 & 2 & 6 & 8 & 3 \\
\hline & Borda points & 14 & 24 & 0 & 6 & 18 & 14 & 10 & 3 & 19 \\
\hline & $\begin{array}{l}\text { Aggregated } \\
\text { Rank }\end{array}$ & 4 & 1 & 9 & 7 & 3 & 4 & 6 & 8 & 2 \\
\hline \multirow{5}{*}{2018} & MAUT & 3 & 1 & 6 & 9 & 4 & 2 & 7 & 8 & 5 \\
\hline & PROMETHEE & 2 & 1 & 6 & 9 & 4 & 5 & 7 & 8 & 3 \\
\hline & TOPSIS & 3 & 1 & 6 & 9 & 4 & 2 & 7 & 8 & 5 \\
\hline & Borda points & 19 & 24 & 9 & 0 & 15 & 18 & 6 & 3 & 14 \\
\hline & $\begin{array}{l}\text { Aggregated } \\
\text { Rank }\end{array}$ & 2 & 1 & 6 & 9 & 4 & 3 & 7 & 8 & 5 \\
\hline
\end{tabular}

When the results in Table 5 are examined, MAALT, AYCES, TEKTU in 2014; MAALT, METUR, TEKTU in 2015; METUR, MAALT, NTHOL in 2016; MAALT, ULAS, NTHOL in 2017 and MAALT, AYCES, PKENT in 2018 ranked first three places in terms of financial performance. Also, it is understood that MAALT's financial performance is generally better than other companies in these five years. MAALT ranked first place in all evaluated years except 2016, which it had second place in.

\section{Conclusion}

When the data of the tourism sector in the last five years are analyzed, negative effects of the regional crises, the expansion of the impact area of terrorism on a global scale, and the global economic crisis. These reasons have led to significant contractions in outbound tourism and inbound tourism. It is observed that the sector was at depression especially in 2015 and 2016. On the other hand, some recovery has been experienced since 2017. 
It is also possible to see the effects of the aforementioned problems in the financial data of tourism companies traded in BIST. After all, eleven publicly-listed tourism companies are ranked according to their financial performance in this study, and similar results were obtained with other studies in the literature. In general, it can be stated that MAALT performed relatively well again in this period. This result is consistent of other studies in which the names of the companies were clearly stated (Ergül, 2014; Özçelik and Kandemir, 2015; Yakut et al., 2015; Erdoğan and Yamaltdinova, 2018). However, especially in 2015 and 2016, it can be stated that the difficult period of the sector was reflected in the financial performance and considering this situation, it can be stated that the existing policies of the companies are inadequate. Considering that the improvement in the last two years has been lived in 2019 , it is necessary to develop new policies in order not to face similar problems in the future.

This study differentiated from the other studies in the literature due to its methodology. While evaluating the data on an annual basis, the objective weighting technique CRITIC was applied to weight the criteria. Besides, while the criteria were weighted, each year's data was used to carry out the analyses performed robustly. In addition, three different techniques, MAUT, PROMETHEE, and TOPSIS were applied in the context of theory and main ideas which are widely used in the MCDM literature. The solutions obtained each technique were integrated by the Borda technique. In this way, it was tried to provide a common solution with more qualified and different opinions. This aspect of the study is thought to provide a new perspective to the literature.

It is thought that the integration of financial performance analysis and efficiency analysis in future studies can yield a more holistic evaluation of tourism companies. Also, it can be stated that the comparison of the estimations to be made with econometric models over the previous years with the latest data of the companies can provide depth understanding.

\section{References}

Bozgeyik, Y. \& Yoloğlu, Y. (2015). Türkiye'de turizm gelirleri ile GSYH arasindaki ilişki: 2002-2014 dönemi, Journal of International Social Research, vol. 8 (40), pp. 627-640.

Brans, J. P. \& Vincke, P. (1985). A Preference ranking organisation method: The PROMETHEE method for multiple criteria decision-making, Management Science, vol. 31(6), pp. 647-656. https://doi.org/10.1287/mnsc.31.6.647

Diakoulaki, D., Mavrotas, G., \& Papayannakis, L. (1995). Determining objective weights in multiple criteria problems: The CRITIC method, Computers \& Operations Research, vol. 22(7), 763-770. https://doi.org/10.1016/0305-0548(94)00059-H

Durucasu, H., Aytekin, A., Saraç, B. \& Orakçı, E. (2017). Current application fields of ELECTRE and PROMETHEE: A literature review, Alphanumeric Journal, vol. 5(2), pp. 229-270. https://doi.org/10.17093/alphanumeric.320235

Ecer, F. \& Günay, F. (2015). Borsa İstanbul'da işlem gören turizm şirketlerinin finansal performanslarının gri ilişkisel analiz yöntemiyle ölçülmesi, Anatolia: Turizm Araştırmaları Dergisi, vol. 25(1), pp. 35-48. https://doi.org/10.17123/atad.vol25iss195016

Erdoğan, M. \& Yamaltdinova, A. (2018). Borsa İstanbul'a kayıtlı turizm şirketlerinin 2011 2015 dönemi finansal performanslarının TOPSISS ile analizi, Optimum: Ekonomi ve Yönetim Bilimleri Dergisi, vol. 5(1), pp. 19-36. https://doi.org/10.17541/optimum.335722

Ergül, N. (2014). BİST-Turizm sektöründeki şirketlerin finansal performans analizi, Çankırı Karatekin Üniversitesi IIIBF Dergisi, vol. 4(1), pp. 325-340. 
Hwang, C. L. \& Yoon, K. (1981). Multiple Attribute Decision Making: A State of the Art Survey. Lecture Notes in Economics and Mathematical Systems, 186. https://doi.org/10.1007/978-3-642-48318-9

Ishizaka, A. \& Nemery, P. (2013). Multi-Criteria Decision Analysis: Methods and Software. John Wiley \& Sons. https://doi.org/10.1002/9781118644898

Karaca, S. \& Özen, E. (2017). Financial failure estimation of companies in BIST tourism index by Altman Model and its effect on market prices. BRAND: Broad Research in Accounting, Negotiation, and Distribution, vol. 8(2), pp. 11-23.

Karadeniz, E., Koşan, 1., Günay, F., \& Dalak, S. (2016). Gri ilişkisel analiz yöntemiyle turizm alt sektörlerinin finansal performanslarının ölçülmesi, Journal of International Social Research, vol. 9(44), pp. 1117-1134.

Karkacıer, O. \& Yazgan, A. E. (2017). Turizm sektöründe Gri İlişkisel Analiz (GİA) yöntemiyle finansal performans değerlemesi, Selçuk Üniversitesi Sosyal Bilimler Enstitüsü Dergisi, vol. 37, pp. 154-162.

Kendirli, S. \& Çankaya, M. (2016). BİST turizm endeksindeki şirketlerde işletme sermayesi yönetiminin karlılık üzerindeki etkisini ölçmeye yönelik bir araştırma, International Review of Economics and Management, vol. 4(2), pp. 46-68.

Lansdowne, Z. F. \& Woodward, B. S. (1996). Applying the Borda ranking method, Air Force Journal of Logistics, vol. 20(2), pp. 27-29.

Leiper, N. (1979). "The framework of tourism: Towards a definition of tourism, tourist, and the tourist industry", Annals of Tourism Research, vol. 6(4), pp. 390-407.

Lippman, D. (2017). Math in Society. Creative Commons BY-SA. https://www.opentextbookstore.com/mathinsociety/

Özçelik, H. \& Kandemir, B. (2015). BİST'de işlem gören turizm işletmelerinin TOPSIS yöntemi ile finansal performanslarının değerlendirilmesi, Balikesir University Journal of Social Sciences Institute, vol. 18(33), pp. 97-114.

Topallı, N. (2015). Turizm sektörünün Türkiye'nin ekonomik büyümesi üzerindeki etkisi: 1963-2011, Uluslararası Íktisadi ve İdari İncelemeler Dergisi, vol. 7(14), pp. 339-352.

Yaralığlu, K. (2010). Karar Verme Yöntemleri, Detay Yayıncılık, Ankara.

Yakut, E., Harbalığlu, M. \& Pekkan, N. Ü. (2015). Turizm Sektöründe BIST'a Kayıtlı İşletmelerin Veri Zarflama Analizi ve Toplam Faktör Verimliliği ile Finansal Performanslarının İncelenmesi, Işsletme Araştırmaları Dergisi (ISARDER), vol. 7(2), pp. 235-257. https://doi.org/10.20491/isader.2015215741

https://biruni.tuik.gov.tr/medas/?kn=74\&locale=tr (Access Date: 10.07.2019)

http://sozluk.gov.tr/ (Access Date: 10.07.2019)

https://www.tursab.org.tr/istatistikler (Access Date: 10.07.2019)

https://www.wttc.org/-/media/files/reports/economic-impact-research/regions2019/world2019.pdf (Access Date: 10.07.2019)

https://blogs.cul.columbia.edu/business/files/2014/02/Worldscope-Data-Definition-GuideIssue-14.2.pdf (Access Date: 11.07.2019), Thompson Reuters, (2013). Worldscope database datatype definitions gpuide. 